\title{
FAA Law, Without the Activism: What If the Bellwether Cases Were Decided by a Truly Conservative Court?
}

\author{
Richard C. Reuben*
}

\section{INTRODUCTION}

Alexander Bickel famously observed that the Supreme Court was "the least dangerous branch" because it is, in theory, the least political institution. ${ }^{1}$ Its job was simply to settle disputes over the meaning of statutes and to decide constitutional questions, but only when absolutely necessary. ${ }^{2}$ Setting the policy of the land just was not its domain. That was for the political branches. ${ }^{3}$

This is good theory, but it hardly reflects reality in practice. Rather, the Court has been a political football since John Adams' midnight appointments in $1801{ }^{4}$ Part of this, of course, is because of the inescapable fact that virtually any choice between statutory or constitutional interpretations has policy implications. The Bill of Rights may be a beautiful, moving, and majestic document, but it is also relatively vague and reveals very little about what it means. While some cases may just be a matter of calling "balls and strikes," 5 people care

* James Lewis Parks Professor of Law, University of Missouri School of Law. I would like to thank the participants at the symposium for their comments on the initial presentation of this material and my research assistant, Kevin Stockmann, for his excellent research assistance. Any errors or omissions are my own.

1. AleXAnder M. Bickel, The Least Dangerous Branch: The Supreme Court at the BAR OF Politics 1, 29-33 (1962). Bickel's ideas have roots in the Federalist Papers. THE FEDERALIST No. 78, at 465 (Alexander Hamilton) (Clinton Rossiter ed., 1961) (“[T]he judiciary, from the nature of its functions, will always be the least dangerous to the political rights of the Constitution; because it will be least in a capacity to annoy or injure ... [because it has] neither FORCE nor WILL, but merely judgment ....”).

2. See BICKEL, supra note 1, at 33, 235.

3. U.S. CONST. art. I, § 1 .

4. KATHLEEn M. SulLivan \& Gerald GunTHER, Constitutional LAW 11 (Robert C. Clark et al. eds., 14th ed. 2001).

5. Confirmation Hearing on the Nomination of John G. Roberts, Jr. to be Chief Justice of the United States Before the S. Comm. on the Judiciary: S. Hearing 109-158, 109th Cong. 56 (2005) (statement of John G. Roberts, Jr., Nominee to be Chief Justice of the United States), 
about the ones that have greater implications. There simply are not right answers about many constitutional or statutory questions, such as those involving affirmative action, abortion, and the death penalty to name just a few hot button issues. In these situations, the ideology of the decision maker matters.

By my estimate, the current ideological battle over the Court began in the late 1950s with the Court's decision in Brown v. Board of Education outlawing racial segregation in public schools. ${ }^{6}$ Though unanimous, it was a very controversial decision at the time and spawned a decade of spirited critique by conservative scholars and politicians. ${ }^{7}$ Inspired by Arizona Senator Barry Goldwater, Richard M. Nixon ran for president in 1968 against the Supreme Court on the promise that he would appoint conservative judges who would end the activism. ${ }^{8}$ And the battle was on, reaching its boiling point with the nomination of thenFederal Circuit Judge Robert Bork ${ }^{9}$ and continuing to a lesser degree with most subsequent high court nominations. In the course of this ongoing debate, conservative jurisprudence has come to be equated with "judicial restraint," 10 while a liberal judicial philosophy has come to be associated with "judicial activism." " Both of these terms are in

http://www.gpoaccess.gov/congress/senate/judiciary/sh109-158/browse.html.

6. 347 U.S. 483, 495 (1954) ("We conclude that in the field of public education the doctrine of 'separate but equal' has no place.”).

7. See David S. Tatel, Judicial Methodology, Southern School Desegregation, and the Rule of Law, 79 N.Y.U. L. REV. 1071, 1089-99 (2004) (discussing the political turmoil surrounding courtordered school desegregation).

8. William G. Ross, The Role of Judicial Issues in Presidential Campaigns, 42 SANTA ClaRA L. ReV. 391, 435-36 (2002); see also THOMAs M. KECK, THE MOST ACTIVIST SUPREME COURT IN History: THE ROAD TO MODERN JUDICIAL CONSERVATISM 94-97 (2004) (explaining how Goldwater's failed campaign strategy for a more conservative Court laid the groundwork for other conservatives to stop the Court from taking an activist stance).

9. See Denis Steven Rutkus et al., TheCapitol.Net, Supreme Court Nominations: Presidential Nomination, the Judiciary CommitTee, Proper Scope of Questioning of Nominees, Senate Consideration, Cloture, AND the Use of the Filibuster 40 n.160 (2010); Tom Lininger, On Dworkin and Borkin', 105 Mich. L. REv. 1315, 1316 (2007) (book review).

10. Charles Gardner Geyh, Can the Rule of Law Survive Judicial Politics?, 97 CoRnelL L. REV. 191, 216-17 (2012) (“[The court critics'] stated goal is for judges to exercise 'judicial restraint,' as exemplified ... by the decisions of Supreme Court conservatives ....”).

11. See Ernest A. Young, Judicial Activism and Conservative Politics, 73 U. Colo. L. Rev. 1139, 1139-40 (2002) (“[T]he current debate raises the question whether an 'activist' court can truly be 'conservative' at all.”). This may be changing in the conservative Court has also been accused of activism in high profile cases. See, e.g., Citizens United v. FEC, 130 S. Ct. 876 (2010) (holding that government may not limit independent expenditures by corporations); Bush v. Gore, 531 U.S. 98 (2000) (holding that a lack of uniform standards for counting votes in recounts violates the Equal Protection Clause, and halting the recount of Florida ballots in the 2000 presidential election). 
reference to the cardinal sin of imposing personal preferences or values into judicial decision-making.

Now, all of this lofty discussion may seem far removed from a short, nuts-and-bolts statute like the Federal Arbitration Act (FAA). But I would submit not so, for there is hardly an area on the Court's docket in which the Court can be alleged to have been more activist than in its arbitration jurisprudence under the FAA. Indeed, the Court's work in this area has arguably been the Taj Mahal of judicial activism, as the Court has taken a simple statute authorizing federal judicial enforcement of agreements between businesses to arbitrate their disputes and has used it to create its own version of civil justice reform-a junior varsity system of private adjudication whose outcomes will be enforced by the courts, just like their varsity counterparts in the federal and state trial courts. ${ }^{12}$ Ironically, virtually all of this work occurred as the Court made its historic shift over the last fifty years from Warren Court liberalism to today's allegedly staunch conservatism.

Much has been written about the errors of the Court's ways on arbitration, and there is no need to traverse that ground yet again. Rather, my task in this Article is to look at several of what I term the Court's bellwether FAA cases through the lens of a conservative judicial philosophy, asking in particular whether they would have come out the same if they had been decided by the truly conservative Court promised by generations of Republican presidents and presidential hopefuls. ${ }^{13}$ As we will see, the answer is a resounding no.

In Part II, I provide a common footing by briefly describing the structure and purpose of the FAA, as well as five bellwether cases decided under the Act. FAA mavens of course can disagree as to whether these are the most important of the Court's long line of FAA case law-such is the stuff of good classroom and cocktail party discussion. But I think most would agree they are certainly very important and often provide the core in arbitration practice guides and casebooks. ${ }^{14}$ In Part III, I turn my focus to identifying the contours of a

12. For an argument that the Court's jurisprudence actually expanded the public system of justice rather than creating a private system of alternative justice, see Richard C. Reuben, Constitutional Gravity: A Unitary Theory of Alternative Dispute Resolution and Public Civil Justice, 47 UCLA L. REv. 949, 1104 (2000). The junior varsity analogy is drawn from Justice Antonin Scalia's brilliant dissent in Mistretta v. United States. 488 U.S. 361, 427 (1989) (Scalia, J., dissenting) (comparing the Federal Sentencing Commission to a "junior varsity" legislature).

13. See generally Ross, supra note 8 (discussing the role judicial appointments have played in elections since 1860).

14. See, e.g., LEONARD L. Riskin ET AL., DisPute RESOlution AND LAWYERS 563-608 (4th 
truly conservative jurisprudence, which I identify as restraint, fidelity to text, and an abiding respect for states' rights. I join these discussions in Part IV by assessing the five bellwether cases identified in Part II according to these principles of conservative jurisprudence. As I will demonstrate, all five fail to meet the conservative standard. Finally, I conclude by musing about what arbitration would be like today if the cases had gone the other way and had been decided by a truly conservative Court.

\section{LAYING THE FOUNDATION: A BRIEF OVERVIEW OF THE FEDERAL ARBITRATION ACT}

\section{A. The Statute}

Congress passed the FAA in 1925 primarily to legislatively reverse the historic "ouster doctrine," a centuries-old common law doctrine under which courts refused to enforce agreements to arbitrate. ${ }^{15}$ It is remarkably simple on its face. After a short list of definitions in section $1,{ }^{16}$ section 2, the heart of the Act, provides that written arbitration agreements will be enforced just like any other agreement, as long as the agreement is enforceable as a matter of contract law. ${ }^{17}$ Section 4 permits a court to compel an unwilling party into arbitration if it is satisfied that there is an enforceable agreement to arbitrate. ${ }^{18}$ Section 3 permits a court to stay related legal proceedings pending arbitration. ${ }^{19}$ Section 5 permits a court to select an arbitrator if the parties cannot agree upon one, ${ }^{20}$ and Section 7 permits an arbitrator to summon and hear witnesses during the arbitration. ${ }^{21}$ Sections 9 and 13 permit the arbitrator to issue an award that may be entered as a court judgment. ${ }^{22}$ After an arbitration, section

ed. 2009) (discussing four of the five cases mentioned in Part II).

15. See generally IAN R. MACNEIL, AMERICAN ARBITRATION LAW: REFORMATION, NATIONALIZATION, INTERNATIONALIZATION 102-21 (1992) (discussing the legislative history and purposes for the FAA); see also Richard C. Reuben, Public Justice: Toward a State Action Theory of Alternative Dispute Resolution, 85 CALIF. L. REV. 577, 599-601 (1997) (discussing the history of the ouster doctrine).

16. 9 U.S.C. $\S 1$ (2006).

17. Id. § 2 .

18. Id. $\S 4$.

19. Id. § 3 .

20. Id. § 5 .

21. Id. § 7 .

22. Id. $\S \S 9,13$. 
10 allows a court to vacate an award where there was corruption, partiality, or other misconduct by the arbitrator, or where the arbitrator exceeded the scope of his or her authority, ${ }^{23}$ while section 11 authorizes a court to modify or correct an award. ${ }^{24}$

\section{B. The Bellwether Cases}

Few will question that the Supreme Court has transformed this relatively narrow, innocuous statute into a powerful engine of civil justice reform, although views do vary widely as to the propriety of the Court's efforts. $^{25}$ Case by case, the Court has built a junior varsity adjudicatory system that now hears many statutory and common law claims that would have been heard by courts of law in years past. This tribunal has broad power to decide legal and non-legal issues ${ }^{26}$ without substantive review (even for clear errors of law), ${ }^{27}$ to determine if obligations to arbitrate have been triggered, ${ }^{28}$ and even to decide the validity of its own jurisdiction, all without applying the law unless the parties so require. ${ }^{29}$ Parties may jointly agree to go to this junior varsity tribunal voluntarily, but high-power players can also force othersconsumers, $^{30}$ employees, ${ }^{31}$ and franchisees, $^{32}$ for example-into

23. Id. § 10 .

24. Id. § 11 .

25. Compare Paul D. Carrington \& Paul H. Haagen, Contract and Jurisdiction, 1996 SuP. CT. REV. 331, 332-33 (arguing that the Court overstepped its bounds by crafting "new national arbitration law”), with Samuel Estreicher, Arbitration of Employment Disputes Without Unions, 66 CHI.-KENT L. REV. 753, 755-57 (1990) (suggesting the appropriateness of this system because of the policy favoring arbitration), and Alan Scott Rau, "The Arbitrability Question Itself”, 10 AM. REV. INT’L ARB. 287, 287-89 (1999) (arguing for separability and its allocation of the gatekeeping role to the arbitrator).

26. See Prima Paint Corp. v. Flood \& Conklin Mfg. Co., 388 U.S. 395, 406 (1967) (“[N]o claim is made that Prima Paint ever intended that 'legal' issues relating to the contract be excluded from arbitration ....”).

27. See Hall Street Assocs., LLC v. Mattel, Inc., 552 U.S. 576, 588-89 (2008) (stating that because of the policy favoring arbitration, judicial review of arbitration awards is limited to the grounds provided in the FAA); Major League Baseball Players Ass'n v. Garvey, 532 U.S. 504, 511 (2001) ("[E]ven 'serious error' on the arbitrator's part does not justify overturning his decision, where, as here, his is construing a contract and acting within the scope of his authority." (citing United Paperworkers Int’l Union v. Misco, Inc., 484 U.S. 29, 38 (1987))).

28. See John Wiley \& Sons Inc. v. Livingston, 376 U.S. 543, 558-59 (1964) (permitting arbitrators to determine whether conditions precedent to an obligation to arbitrate have been metthe so-called "procedural arbitrability" doctrine).

29. See Prima Paint, 388 U.S. at 425 (Black, J., dissenting) (arguing that the Court gave arbitrators the power to make determinations as to their own jurisdiction).

30. Hill v. Gateway 2000, Inc., 105 F.3d 1147, 1148-49 (7th Cir. 1997).

31. Gilmer v. Interstate/Johnson Lane Corp., 500 U.S. 20, 32-33 (1991). 
arbitration, unless the low-power player wants to bring a class action. ${ }^{33}$ By statute, the triggering mechanism for entry into the Court's junior varsity tribunal is merely any written agreement to arbitrate any issue that falls within the furthest reaches of the Commerce Clause, ${ }^{34}$ and this agreement will preempt any state law that interferes with its goals or objectives. $^{35}$ Finally, unlike any other areas of federal law, this junior varsity tribunal has its own body of substantive law that applies in both federal and state courts. ${ }^{36}$ By virtually any measure, this is quite a body of work, and it likely will only continue to grow if the Court continues to hear on average an arbitration case or two every Term.

It obviously took many cases to build this edifice. But five cases can be seen as especially important building blocks in this process. I call these "the bellwether cases" and describe them further below in order of decision.

\section{Prima Paint Corp. v. Flood \& Conklin Manufacturing Co. and} Separability

In Prima Paint Corp. v. Flood \& Conklin Manufacturing Co., the Court dealt with a specific but important question - whether an arbitrator can decide the validity of the very agreement that gives rise to his jurisdiction in the first place. ${ }^{37}$ The typical situation in which this would arise is a contract for a sale or service that included an arbitration provision. For example, in Prima Paint, the paint manufacturer hired Flood \& Conklin, a consulting firm, to assist on certain issues. ${ }^{38}$ The relationship was rocky from the start, and Prima Paint filed suit in federal district court, seeking to rescind the consulting contract on formation grounds, arguing that Flood \& Conklin had fraudulently induced it to

\footnotetext{
32. Doctor's Assocs., Inc. v. Casarotto, 517 U.S. 681, 688 (1996).

33. Stolt-Neilsen S.A. v. AnimalFeeds Int'l Corp., 130 S. Ct. 1758, 1775-76 (2010) (refusing to construe silence as permitting class actions to proceed in arbitration).

34. Allied-Bruce Terminix, Cos. v. Dobson, 513 U.S. 265, 268 (1995).

35. AT\&T Mobility LLC v. Concepcion, 131 S. Ct. 1740, 1753 (2011); Southland Corp. v. Keating, 465 U.S. 1, 15-16 (1984).

36. Southland, 465 U.S. at $15-16$.

37. 388 U.S. 395, 402 (1967).

38. Id. at 397. The precise nature of the consulting agreement is unclear, but according to Prima Paint's president, Flood \& Conklin was to "consult, advise, assist and help [Prima Paint] so as to insure a smooth transition of manufacturing operations to Maryland from New Jersey, together with the sales and servicing of customer accounts and the retention of the said customers." Id. at 401
} n.6. 
enter the contract by portraying itself as solvent. ${ }^{39}$ The question for the Court, then, was whether the arbitrator or the courts had the power to decide the fraud claim if the very consulting agreement giving rise to the arbitrator's jurisdiction was itself legally invalid because it was fraudulently induced.

The circuits had split on the question, ${ }^{40}$ and the Supreme Court, in a 6-3 vote, upheld what has come to be known as the principle of separability under the FAA. ${ }^{41}$

Under $\S 4 \ldots$ the federal court is instructed to order arbitration to proceed once it is satisfied that "the making of the agreement for arbitration or the failure to comply (with the arbitration agreement) is not in issue.” Accordingly, if the claim is fraud in the inducement of the arbitration clause itself-an issue which goes to "the making" of the agreement to arbitrate- the federal court may proceed to adjudicate it. But the statutory language does not permit the federal court to consider claims of fraud in the inducement of the contract generally. ${ }^{42}$

The separability doctrine was a significant expansion of the arbitrator's powers under the FAA on the policy question of who should decide the validity of so-called "container" contracts. Under the doctrine, it is arbitrators, not courts, who decide the validity of the primary contract. ${ }^{43}$ Courts only decide the validity of an arbitration clause in a container contract if the claim of fraud, mistake, or other contract defect is directed exclusively at the arbitration provision itself. ${ }^{44}$

\section{Southland Corp. v. Keating and Preemption}

In Southland Corp. v. Keating, the Supreme Court held for the first time that the FAA applies in state courts as well as federal courts, and

39. Id. at 398.

40. Compare Prima Paint Corp. v. Flood \& Conklin Mfg. Co., 360 F.2d 315, 318 (2d Cir. 1966) (granting broad authority to the arbitrator to decide this issue), with Lummus Co. v. Commonwealth Oil Ref. Co., 280 F.2d 915, 923-24 (1st Cir. 1960) (holding that this issue was a question for the court).

41. Prima Paint, 388 U.S. at 402-04; see also Richard C. Reuben, First Options, Consent to Arbitration, and the Demise of Separability: Restoring Access to Justice for Contracts with Arbitration Provisions, 56 SMU L. REV. 819, 838-40 (2003) (discussing generally the doctrine of separability).

42. Prima Paint, 388 U.S. at 403-04 (quoting 9 U.S.C. § 4 (2006)).

43. See Reuben, supra note 41 , at $838-40$.

44. Id. 
that it preempts contrary state law. ${ }^{45}$ In Southland, several 7-Eleven franchisees sued the franchisor in state court, alleging fraud, breach of contract, breach of fiduciary duty, and-critically for the purposes of this Article-failure to comply with the disclosure requirements of the California Franchise Investment Law (CFIL). ${ }^{46}$ The CFIL required judicial consideration of any claim brought under state law, ${ }^{47}$ but the franchise agreements all contained arbitration clauses requiring the arbitration of "[a]ny controversy or claim arising out of or relating to this Agreement." ${ }^{\text {"48 }}$ Southland, the franchisor, moved to compel arbitration. ${ }^{49}$ The trial court granted Southland's motion for all claims other than the CFIL claim, but the California Court of Appeal reversed, holding that the CFIL claim was arbitrable as well. ${ }^{50}$ The California Supreme Court reversed the appellate court, finding that the CFIL claim could not be compelled into arbitration. ${ }^{51}$ That decision, however, was reversed by the U.S. Supreme Court:

We discern only two limitations on the enforceability of arbitration provisions governed by the Federal Arbitration Act: they must be part of a written maritime contract or a contact "evidencing a transaction involving commerce" and such clauses may be revoked upon "grounds as exist at law or in equity for the revocation of any contract." We see nothing in the Act indicating that the broad principle of enforceability is subject to any additional limitations under State law. ${ }^{52}$

Chief Justice Burger, writing for the majority, also responded to two points that Justice O'Connor made in her dissent. First, Justice O'Connor had argued that the FAA was a procedural statute solely for use in federal court, ${ }^{53}$ but Chief Justice Burger insisted that the use of the term "involving commerce" in section 2 established the Act's preemptive effect. $^{54}$

We would expect that if Congress, in enacting the Arbitration Act, was

45. 465 U.S. 1, 16 (1984).

46. Id. at 4.

47. Id. at 10 (discussing the California Supreme Court's interpretation of Cal. Corp. Code $\S 31512$ (West 1977)).

48. Id. at 4.

49. Id.

50. Id. at $4-5$.

51. Id. at 5 .

52. Id. at 10-11 (quoting 9 U.S.C. § 1 (2006)).

53. Id. at 25 (O’Connor, J., dissenting).

54. Id. at 14 (majority opinion). 
creating what it thought to be a procedural rule applicable only in federal courts, it would not so limit the Act to transactions involving commerce. On the other hand, Congress would need to call on the Commerce Clause if it intended the Act to apply in state courts. Yet at the same time, its reach would be limited to transactions involving interstate commerce. We therefore view the "involving commerce" requirement in $\S 2$, not as an inexplicable limitation on the power of the federal courts, but as a necessary qualification on a statute intended to apply in state and federal courts. ${ }^{55}$

Second, Justice O'Connor argued that state law claims could not be arbitrated when raised in state court, ${ }^{56}$ but again Chief Justice Burger dismissed the argument as permitting a result that would encourage forum-shopping. ${ }^{57}$ The Chief Justice continued:

We are unwilling to attribute to Congress the intent, in drawing on the comprehensive powers of the Commerce Clause, to create a right to enforce an arbitration contract and yet make the right dependent for its enforcement on the particular forum in which it is asserted. And since the overwhelming proportion of all civil litigation in this country is in the state courts, we cannot believe Congress intended to limit the Arbitration Act to disputes subject only to federal court jurisdiction. ${ }^{58}$

\section{Gilmer v. Interstate/Johnson Lane Corp. and the Mandatory Arbitration of Statutory Claims}

Gilmer v. Interstate/Johnson Lane Corp. may be the most significant case of the modern arbitration era because it approved the use of socalled mandatory arbitration provisions in consumer, employment, and other standard form contracts, even when statutory rights are at stake. ${ }^{59}$ In Gilmer, Interstate/Johnson Lane hired Robert Gilmer as a Manager of Financial Services. ${ }^{60}$ As part of the hiring process, Gilmer was required

55. Id. at $14-15$.

56. Id. at 31-33 (O’Connor, J., dissenting)

57. Id. at 15 (majority opinion).

58. Id.

59. 500 U.S. 20, 33-35 (1991). Even the term "mandatory arbitration" is controversial. See Stephen J. Ware, Contractual Arbitration, Mandatory Arbitration, and State Constitutional JuryTrial Rights, 38 U.S.F. L. REV. 39, 43 (2003) ("I ask Professor Sternlight (and others) to stop calling contractual arbitration-mandatory arbitration.”). But see Jean R. Sternlight, In Defense of Mandatory Binding Arbitration (if Imposed on the Company), 8 NEV. L.J. 82, 82 n.1 (2007) (disagreeing with Professor Ware's semantic argument, stating that "this phrase perfectly describes companies' practice of requiring their consumers and employees to submit future and yet unknown disputes to binding arbitration, rather than to litigation”).

60. 500 U.S. at 23 . 
to sign a registration application with the New York Stock Exchange (NYSE) in which he agreed "to arbitrate any dispute, claim, or controversy" arising between him and the company. ${ }^{61}$ Interstate/Johnson Lane fired Gilmer six years later, when he was 62, and hired a 28-yearold with less experience to replace him. ${ }^{62}$ Gilmer sued the company in federal district court alleging violations of the Age Discrimination in Employment Act (ADEA). ${ }^{63}$ The company moved to compel arbitration under the FAA, but the trial court denied the motion. ${ }^{64}$ The Fourth Circuit reversed, and Gilmer appealed the case to the Supreme Court. ${ }^{65}$ The questions before the Supreme Court were whether Gilmer's ADEA claims were arbitrable, and if so, whether the compulsion into arbitration by virtue of a pre-dispute arbitration clause constituted an invalid prospective waiver of Gilmer's legal rights. ${ }^{66}$

The Court used the case to send a very clear message to the lower courts that the ouster doctrine was dead. Citing three opinions that the Court had decided within the previous six years, Justice White disposed of the ADEA arbitrability issue summarily:

It is by now clear that statutory claims may be the subject of an arbitration agreement, enforceable pursuant to the FAA.... In these cases we recognized that "[b]y agreeing to arbitrate a statutory claim, a party does not forgo the substantive rights afforded by the statute; it only submits to their resolution in an arbitral, rather than a judicial, forum.,, 67

Justice White also rejected a variety of generalized challenges to the NYSE process, all of which "'res[t] on suspicion of arbitration as a method of weakening the protections afforded in the substantive law to would-be complainants,' and as such, they are 'far out of step with our current strong endorsement of the federal statutes favoring this method of

61. Id. (internal quotation marks omitted) (quoting language from the agreement).

62. Petition for Writ of Certiorari at 4, Gilmer v. Interstate/Johnson Lane Corp., 500 U.S. 20 (No. 98-18), 1990 WL 10022915 at *4.

63. Gilmer, 500 U.S. at 23-24.

64. Id. at 24 .

65. Id.

66. Id. at $23,26-27$.

67. Id. at 26 (alteration in original) (quoting Mitsubishi Motors Corp. v. Soler ChryslerPlymouth, Inc., 473 U.S. 614, 628 (1985)) (citing Rodriguez de Quijas v. Shearson/Am. Express, Inc., 490 U.S. 477 (1989); Shearson/Am. Express, Inc. v. McMahon, 482 U.S. 220 (1987); Mitsubishi Motors, 473 U.S. 614). 
resolving disputes." "68 Put another way, to the extent that one might have concerns about arbitrator bias, disparities in bargaining power, and the fairness of procedures - such as discovery limitations, the convention against written opinions, and the unavailability of review-they must be claimed and proved with particularity because arbitration as a process has the benefit of the doubt. ${ }^{69}$

\section{Circuit City Stores, Inc. v. Adams and the Employee Exemption}

The FAA has a broad sweep with few statutory exceptions. One of those exceptions is found in section 1, which concludes by stating that "nothing herein contained shall apply to contracts of employment of seamen, railroad employees, or any other class of workers engaged in foreign or interstate commerce.,"70 The meaning of "seamen" and "railroad employees" probably seemed clear to the FAA's drafters, and their exclusion from the FAA seemed necessary. These workers were generally subject to collective bargaining agreements that included their own arbitration systems, ${ }^{71}$ so there was no need for the FAA's anti-ouster provisions to reach them. The language "workers engaged in foreign or interstate commerce" was less clear, and as the holy war over mandatory arbitration continued to wage in the 1990s, plaintiffs' employment lawyers seized on this language to argue that employment cases were intended to be excluded from the FAA entirely. ${ }^{72}$

In Circuit City Stores, Inc. v. Adams, the Supreme Court rejected this claim by a $5-4$ vote and, in an opinion written by Justice Kennedy, held that the exemption only applied to workers in the transportation industry. ${ }^{73}$ Such an interpretation was necessary, according to Justice Kennedy, because of the doctrine of ejusdem generis - a longstanding maxim of statutory interpretation essentially requiring the similar

68. Id. at 30 (alteration in original).

69. See id. at 30-33 (dismissing the plaintiff's challenges to the potential for bias, the adequacy of arbitration procedures, and the inequality of bargaining power as generalized and contrary to the Court's endorsement of arbitration as a favored means of dispute resolution).

70. 9 U.S.C. $\S 1$ (2006).

71. See Tenney Eng'g, Inc. v. United Elec. Radio \& Mach. Workers, Local 437, 207 F.2d 450, 452 (1953) (stating that seamen and railroad employees were classes of workers as to whom special arbitration legislation had already been provided at the time of the drafting of the FAA).

72. See generally Matthew W. Finkin, "Workers' Contracts" Under the United States Arbitration Act: An Essay in Historical Clarification, 17 BERKELEY J. EMP. \& LAB. L. 282 (1996) (analyzing the historical context of the exception to the FAA to conclude that the Act exempts all employment over which Congress has constitutional authority).

73. 532 U.S. 105, 109 (2001). 
interpretation of words listed together in a statute. ${ }^{74}$ Thus, Justice Kennedy found, the "any other workers" clause is a residual clause that "should be read to give effect to the terms 'seamen' and 'railroad employees,' and should itself be controlled and defined by reference to the enumerated categories of workers which are recited just before it," specifically transportation workers. ${ }^{75}$ Justice Kennedy added that the Court would have reached the same result even if the "any workers" clause stood alone instead of being in concert with other words because of the Court's broad policy favoring arbitration. ${ }^{76}$

\section{AT\&T Mobility LLC v. Concepcion and Class Arbitration}

In recent years, the battle over arbitration has shifted somewhat from attacks on the mandatory arbitration systems upheld in Gilmer to questions of whether claims can be aggregated in arbitration as class actions and, more pointedly, whether the drafters of arbitration clauses can include so-called "class action waivers" that preclude class actions in arbitration. The Supreme Court weighed in on class action waivers in its watershed ruling in AT\&T Mobility LLC $v$. Concepcion, holding that state laws disallowing class action waivers in arbitration are preempted by the FAA. ${ }^{77}$

Class actions have been controversial as a means of managing minor claims because of the potential for abuse by plaintiffs' lawyers, who are able to generate large fees while producing only a small recovery for individual class members. Concepcion had every appearance of being such a case, as the claim was brought on behalf of AT\&T cell phone plan customers who were told in published advertisements that their phones would be free, but who were nonetheless charged sales taxes for the transactions. $^{78}$ AT\&T's cell phone plan contracts contained an arbitration provision that included a class action waiver, meaning, according to AT\&T, that anyone who wanted to challenge the sales tax charge would have to do so individually in arbitration rather than collectively through a class action. ${ }^{79}$ When AT\&T customers filed their claims as a class action in a California federal district court, AT\&T

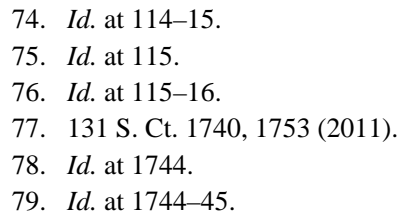


moved to compel arbitration, ${ }^{80}$ and the fight was on.

While Concepcion sounded in class action, and in some respects was all about class action, the key doctrinal issue for purposes of the FAA was preemption. Several years earlier, the California Supreme Court had decided in Discover Bank v. Superior Court to create a rule for the application of its general unconscionability law to determine whether class action waivers in the arbitration context were unconscionable. ${ }^{81}$ Under that rule:

[W]hen the waiver is found in a consumer contract of adhesion in a setting in which disputes between the contracting parties predictably involve small amounts of damages, and when it is alleged that the party with the superior bargaining power has carried out a scheme to deliberately cheat large numbers of consumers out of individually small sums of money, then ... the waiver becomes in practice the exemption of the party "from responsibility for [its] own fraud, or willful injury to the person or property of another." Under these circumstances, such waivers are unconscionable under California law and should not be enforced. ${ }^{82}$

Because Concepcion was brought in federal court in California on diversity grounds, the district court applied the Discover Bank rule and held the class action waiver in the AT\&T Mobility agreements unconscionable, and the Ninth Circuit agreed. ${ }^{83}$ Before the Supreme Court, however, AT\&T Mobility argued that the Discover Bank rule was preempted by the FAA, and the Court agreed. ${ }^{84}$ "Although $\S 2$ 's saving[s] clause preserves generally applicable contract defenses, nothing in it suggests an intent to preserve state-law rules that stand as an obstacle to the accomplishment of the FAA's objectives,” Justice Scalia wrote for the Court. ${ }^{85}$

California's Discover Bank rule... interferes with arbitration. Although the rule does not require classwide arbitration, it allows any party to a consumer contract to demand it ex post. The rule is limited to adhesion contracts, but the times in which consumer contracts were anything other than adhesive are long past. The rule also requires that damages be predictably small, and that the consumer allege a scheme to

\footnotetext{
80. Id.

81. 113 P.3d 1100, 1106-10 (Cal. 2005), abrogated by Concepcion, 131 S. Ct. 1740.

82. Id. at 1110 (alteration in original) (quoting CAL. CIV. CODE $\S 1668$ (West 1997)).

83. Concepcion, 131 S. Ct. at 1745.

84. Id. at $1745,1753$.

85. Id. at 1748 .
} 
cheat consumers. The former requirement, however, is toothless and malleable (the Ninth Circuit has held that damages of $\$ 4,000$ are sufficiently small), and the latter has no limiting effect, as all that is required is an allegation. Consumers remain free to bring and resolve their disputes on a bilateral basis under Discover Bank, and some may well do so; but there is little incentive for lawyers to arbitrate on behalf of individuals when they may do so for a class and reap far higher fees in the process. And faced with inevitable class arbitration, companies would have less incentive to continue resolving potentially duplicative claims on an individual basis. ${ }^{86}$

Scholars and courts are just beginning to assess the impact and limitations of the Court's still freshly minted opinion. But in spelling out the potentially significant preemption limits on section 2's savings clause for the first time, Concepcion will surely stand among the significant monuments of the Court's arbitration jurisprudence.

\section{THE CONSERVATIVE JUdiCIAL PHILOSOPHY}

The foregoing cases are five bellwether cases in the Court's FAA law - a case law that was primarily decided by a Court promised to be more conservative by Republican presidential candidates and presidents who had the majority of the appointments during this time period. ${ }^{87}$ This Article now turns its focus to the question of whether these cases were in fact decided conservatively. This inquiry necessarily begins by describing what is meant by a conservative judicial philosophy, a task accomplished through an exploration of the views of three of legal conservatism's most powerful icons of the last half century-Alexander Bickel, Antonin Scalia, and William Rehnquist.

\section{A. Alexander Bickel and the Rationale for Restraint}

Yale law professor Alexander Bickel is often considered the grandfather of modern judicial conservatism because of his seminal writings on conservative constitutional theory. ${ }^{88}$ Bickel's story begins

86. Id. at 1750 (emphasis in original) (citations omitted).

87. See supra notes 8-11 and accompanying text.

88. See Adam J. White, The Burkean Justice: Samuel Alito's Understanding of Community and Tradition Distinguishes Him from His Supreme Court Colleagues, WKLY. STANDARD, July 18, 2011, available at http://www.weeklystandard.com/articles/burkean-justice_576470.html (last visited Mar. 11, 2012) (providing a brief biography of Bickel and discussing his influence on others, especially Justice Alito). 
for all practical purposes in 1952, when he clerked for Supreme Court Justice Felix Frankfurter. ${ }^{89}$ The term was noted for the Court's decision to hear re-arguments on a school desegregation case from Kansas, Brown $v$. Board of Education - a decision that relied heavily on a memorandum by Bickel making the case for re-argument. ${ }^{90}$ In 1956, Bickel joined the faculty of Yale Law School, where he remained throughout a prolific, albeit relatively brief, career as a constitutional scholar and occasional advocate, ${ }^{91}$ most famously arguing (and winning) the Pentagon Papers case on behalf of the New York Times. ${ }^{92}$

Bickel came out of the Legal Process tradition, ${ }^{93}$ a school that generally argued that legal policy should be set by neutral legal principles rather than by political considerations or the personal preferences of the Justices, and strived to understand and articulate what those principles should be. ${ }^{94}$ Bickel's contribution to this literature was significant and was set out primarily in an important Foreword to the Harvard Law Review in 1961 entitled The Passive Virtues ${ }^{95}$ and in a book released a year later extending that work called The Least Dangerous Branch. ${ }^{96}$ The central thesis of his work now borders on conventional wisdom, a fact that alone attests to its importance.

The starting point is what Bickel called "the counter-majoritarian difficulty" with judicial review-judicial review is not specifically provided for in the written Constitution and is therefore in need of strong justification because its practical effect is to permit the judiciary to invalidate the work of the political, or majoritarian, branches of our constitutional democracy. ${ }^{97}$ Simply raising this issue was a monumental

89. See id. It is no small irony that Frank E.A. Sander, who many view as the father of the modern ADR movement, served as Frankfurter's clerk in the next term. John David Fassett et al., Supreme Court Law Clerks' Recollections of Brown v. Board of Education, 78 ST. JOHN's L. REv. 515, 527 (2004).

90. Paul Craig Roberts \& Lawrence M. Stratton, The New Color Line: How Quotas AND PRIVILEGE DESTROY DEMOCRACY 39-40 (1995).

91. See White, supra note 88 (briefly outlining Bickel's career at Yale Law School).

92. New York Times Co. v. United States, 403 U.S. 713, 713-14 (1971) (per curiam).

93. The seminal work on legal process is HenRy M. HART, JR. \& Albert M. SACKs, The Legal Process: Basic Problems in the Making and ApPlication of LAW (1958).

94. See Herbert Wechsler, Toward Neutral Principles of Constitutional Law, 73 HARV. L. REV. 1, 7-9, 15-19 (1959) (discussing the sentiment that political considerations should not shape judicial policy).

95. Alexander M. Bickel, The Supreme Court 1960 Term-Foreword: The Passive Virtues, 75 HARV. L. REV. 40 (1961).

96. BICKEL, supra note 1.

97. Id. at $16-23$. 
contribution, as it arguably started the search for a normative theory of judicial review that continues to this day.

In Bickel's view, the counter-majoritarian difficulty counseled enormous restraint by the unelected Court. ${ }^{98}$ He believed that the Court had what we today might call great institutional capital and that its reserves should be drawn upon wisely, only when necessary, and should not be squandered on issues more prudently left to the elective branches. ${ }^{99}$ The protests that followed the Brown decision may not have made Earl Warren flinch, but they clearly were instructive to the young Alexander Bickel.

Bickel articulated this sense of restraint, or prudence, through the concept of "passive virtues," or the virtues of the Court not deciding constitutional issues if it does not need to. ${ }^{100}$ Bickel also offered a methodology for implementing this vision, suggesting that the Court should control its docket by refusing to decide a case in which there is no consensus as to intensely contested matters. ${ }^{101}$ Rather, such cases should be dismissed or decided on procedural grounds of ripeness, mootness, standing, or political question rather than on the merits. ${ }^{102}$ To the extent that the merits need to be reached, they should be decided on narrow grounds, such as statutory interpretation or a fact-specific constitutional construction. ${ }^{103}$

Thus, Bickel laid the intellectual foundation for what came to be the conservative judicial movement. This occurred in the 1960s, at the height of the Warren Court's expansion of constitutional rights, and Bickel's voice was an important scholarly critique of that movement. It squared well with the lingering frustration over Brown, as well as conservative apoplexy over the Warren Court's expansion of rights for criminal defendants, political protesters, welfare recipients, and other rights proponents. ${ }^{104}$ Such cases made the Warren Court a convenient target for Richard Nixon to campaign against in his nearly successful presidential run in $1960,{ }^{105}$ and the appointment of judges who would

\footnotetext{
98. Id. at 29-33.

99. Id. at 33.

100. See id. at 111-98 (elaborating on the concept of passive virtues).

101. See id. at 113-27 (advocating the use of the power to decline to decide cases).

102. Id. at 125-26.

103. See id. at $169-83$ (advocating deciding cases on narrow grounds).

104. See generally KECK, supra note 8, at 71-93 (discussing the expansion of rights under the Warren Court).

105. See Ross, supra note 8, at 423-26 (describing the political storm surrounding the Warren
} 
take a limited view of the Constitution and of federal judicial power has been a mantra of Republican presidential candidates ever since. ${ }^{106}$ It was the commitment to this philosophy that led President Reagan to appoint then-Associate Justice William Rehnquist to replace the retiring Chief Justice Warren Burger and Circuit Judge Antonin Scalia to fill Rehnquist's seat on the Supreme Court in 1986, ${ }^{107}$ President George H.W. Bush to appoint Clarence Thomas to the Court in $1991,{ }^{108}$ and George W. Bush to appoint former Rehnquist Court clerk John Roberts and Circuit Judge Samuel Alito to succeed Sandra Day O'Connor in $2005 .{ }^{109}$ Indeed, it is no surprise that Justice Alito paid homage to Bickel during his confirmation hearings, to the chagrin of Senate Democrats. ${ }^{110}$

This is not to suggest that Bickel's influence was so transcendent as to affect the broader political and social environment, in which the country was becoming more conservative. Rather, I suggest that his influence was more subtle-providing an important part of the theoretical foundation that could support the larger political developments that were occurring. While the Warren Court made-and, remarkably, continues to make - an easy target for politicians to run against, with Republican presidents and candidates promising to appoint judges who will apply the law rather than make it, Bickel's prudentialism helped point the doctrinal path for more conservative judges to follow in turning the judiciary from left to right. It provided a template into which the larger set of conservative values could easily settle. These values came from across the spectrum of conservative interests, including the promotion of economic ${ }^{111}$ and property rights, ${ }^{112}$ the protection of

Court and its role in political campaigns).

106. See id. at 427-72 (outlining the role of judicial appointments in elections between 1964 and 2000)

107. Supreme Court Nominations, Present-1789, U.S. SENATE, http://www.senate.gov/ pagelayout/reference/nominations/Nominations.htm (last visited Mar. 11, 2012).

108. Id.

109. Id. See also Jeffrey Rosen, Can Bush Deliver a Conservative Supreme Court?, N.Y. TIMES, Nov. 14, 2004, at 4 ("By promising to appoint strict constructionists, Mr. Bush has embraced the mantra of every Republican president since Richard Nixon, who first made that promise in his 1968 campaign.”).

110. "I discovered the writings of Alexander Bickel advocating judicial restraint, and it was largely for this reason that I decided to go to Yale Law School.” Ronald B. Standler, History of the Nomination of Samuel Alito: How and Why He Was Confirmed 52 (Feb. 12, 2006) (unpublished manuscript) (quoting Samuel B. Alito, Job Application (Nov. 15, 1985)) (internal quotation marks omitted), available at http://www.rbs0.com/alito.pdf.

111. See Stephen E. Gottlieb, Does What We Know About the Life Cycle of Democracy Fit Constitutional Law?, 61 RUTGERS L. REV. 595, 618-21 (2009) (describing the "connection between economic justice and political democracy”). 
traditional moral values ${ }^{113}$ and original constitutional intent, ${ }^{114}$ the contraction of the role of the courts in public life, the limitation of civil and criminal rights, ${ }^{115}$ the heavier reliance on formalism ${ }^{116}$ and textualism rather than penumbras and implied rights, ${ }^{117}$ and the commitment to constitutional "colorblindness" regardless of its costs. ${ }^{118}$ As such, Bickel's work gives rise to the first rule of a conservative judicial philosophy: the Supreme Court should exercise its judicial power, especially constitutional power, with great restraint and deference to the political branches on policy issues.

\section{B. Justice Scalia and Statutory Interpretation}

If there were a statutory counterpart to the constitutionalist Alexander Bickel, a godfather of conservative statutory interpretation, it would be Supreme Court Associate Justice Antonin Scalia. ${ }^{119}$ Both as a law professor before joining the bench, and later as a Justice, Scalia has definitively called for a textual approach to statutory interpretation. ${ }^{120}$ Scalia's plea, like Bickel's before him, is one of restraint. ${ }^{121}$ Where Bickel's concern was about unelected judges rather than the legislature

112. See Ilya Somin, What If Kelo v. City of New London Had Gone the Other Way?, 45 IND. L. REV. 21, 29 (2011) (noting that Justice Kennedy has provided the crucial fifth vote for several conservative Supreme Court victories on property rights).

113. See generally Mark R. Thompson, Note, When God Collides with Race and Class: Working-Class America's Shift to Conservatism, 68 U. PITT. L. REV. 243 (2006) (discussing the shift toward conservatism and the protection of "traditional" moral values in American society).

114. See James E. Ryan, Laying Claim to the Constitution: The Promise of New Textualism, 97 VA. L. REV. 1523, 1529-32 (2011) (outlining the "rise and fall of original intent").

115. See Yale Kamisar, The Warren Court and Criminal Justice: A Quarter-Century Retrospective, 31 TULSA L.J. 1, 3-5 (1995) (noting "an atmosphere that was unfavorable to the continued vitality of the Warren Court's mission in criminal cases" and describing some of the decisions handed down during that era).

116. See Victoria F. Nourse \& John P. Figura, Toward a Representational Theory of the Executive, 91 B.U. L. REV. 273, 291 (2011) (reviewing STEVEN G. CALABRESI \& CHRISTOPHER S. Yoo, The Unitary Executive: Presidential Power from Washington to Bush (2008)) ("Formalism has been considered a conservative version of the separation of powers ....").

117. See Young, supra note 11, at 1210 (noting that "conservatives are generally thought to oppose the recognition of unenumerated rights").

118. See Reva B. Siegel, From Colorblindness to Antibalkanization: An Emerging Ground of Decision in Race Equality Cases, 120 YALE L.J. 1278, 1282-83 (2011) (noting conservative support for colorblindness at all levels of federal policy).

119. See generally James Edward Wyszynski, Jr., Comment, In Praise of Judicial Restraint: The Jurisprudence of Justice Antonin Scalia, 1989 DET. C.L. REV. 117 (discussing Justice Scalia's conservatism).

120. Id. at 132 .

121. Id. at 141 . 
making policy in a democracy, Scalia's is about unelected judges using various tools of statutory interpretation-intent, purpose, and legislative history-to impose their own policy preferences into the reading of statutes. $^{122}$

122. See, e.g., Baze v. Rees, 553 U.S. 35, 89 (2008) (Scalia, J., concurring) (stating that unelected judges should defer to the will of the people). 
Scalia's approach to statutory interpretation is commonly called textualism, or sometimes more accurately "new textualism," because it emphasizes the text of the statute and explicitly eschews any attempt to ascertain legislative intent or purpose, much less legislative history. ${ }^{123}$ For Scalia, reflecting perhaps his law and economics background, no single or controlling legislative intent can exist because 435 representatives, 100 senators, and a president may all have very different intentions with respect to why they approved a statute, if they approved at all. ${ }^{124}$ The idea of legislative purpose is similarly elusive because a statute may have many different purposes, any one of which (but not others) could have been compelling to a particular legislator, again making it impossible to identify a clear statutory purpose. ${ }^{125}$ Finally, legislative history is particularly treacherous for Scalia because there are so many forms of legislative history-speeches, committee reports, and testimony, for example-that one can easily manipulate it to mean whatever one wants. ${ }^{126}$

For Scalia, statutory interpretation simply comes down to the words that are in the statute. Nothing more, and nothing less. Ambiguities of course will still arise, but they may be resolved in one of two ways. The first is with the dictionary, preferably one that was in use at the time the statutory language at issue was drafted. ${ }^{127}$ The second is by reference to canons or maxims of statutory interpretation-longstanding principles of judging that have been passed down from generation to generation. ${ }^{128}$ Many of these maxims reflect the kind of restraint in judging that characterizes the conservative judicial movement. For example, statutes in derogation of the common law should be interpreted narrowly. ${ }^{129}$ Or statutes should be construed narrowly, and their exceptions read broadly. ${ }^{130}$ Both of these canons limit the reach of government's power

123. Scalia's particular brand of textualism has been called "new textualism" because traditional textualism permits some reference to intent and purpose, while Scalia's "new textualism" rejects even these interpretive techniques. See William N. Eskridge, Jr., The New Textualism, 37 UCLA L. REV. 621 (1990) (coining the phrase "new textualism" and discussing Justice Scalia's role in its development); see also Jonathan T. Molot, The Rise and Fall of Textualism, 106 COLUM. L. REv. 1, 66-67 (2006) (noting that Justice Scalia has emphasized dictionary definitions rather than legislative intent).

124. Molot, supra note 123, at 27-28 \& n.114.

125. Id. at 28.

126. Id. at 28-29.

127. See id. at 66-67 (providing an example of this approach taken by Scalia).

128. Id. at 44-46.

129. See, e.g., Pierson v. Ray, 386 U.S. 547, 561 (1967).

130. See, e.g., In re Brock, 499 N.W.2d 752, 761 (Mich. 1993) (citing La Court v. Von Platen- 
and, therefore, fit comfortably within a conservative judicial tradition. The textualist construction of statutes, then, may be identified as a second principle of the modern conservative jurisprudence.

\section{Chief Justice Rehnquist and the Restoration of "Federalism"}

The embodiment of judicial conservatism during the period of these bellwether cases was surely Chief Justice William H. Rehnquist, a 1952 clerk for Justice Robert H. Jackson, ${ }^{131}$ who Nixon tapped in 1971 to replace Justice John Marshall Harlan II as Associate Justice. ${ }^{132}$ Rehnquist quickly staked out his territory as the Court's most conservative Justice, and President Ronald Reagan appointed Rehnquist Chief Justice, succeeding Warren Burger in 1986. ${ }^{133}$ Throughout his tenure on the Court, Chief Justice Rehnquist's brand of conservatism reflected the political ideology of the Grand Old Party. He had worked on the 1964 presidential campaign of Arizona Senator Barry Goldwater, ${ }^{134}$ whose anti-government, anti-Washington appeal laid the ideological foundation for a generation of Republican leaders from Nixon and Reagan to the Bushes.

On the Court, Chief Justice Rehnquist would come to defer to the government position, but his conservative signature would be his strong belief in states' rights. ${ }^{135}$ He believed in the Constitution as a document limiting an already limited government and read the Tenth Amendment as a broad and active reservation of powers to the states. ${ }^{136}$ As Chief Justice, he led a "federalism revolution," 137 limiting federal power by ruling that federal minimum wage laws do not apply to state government employees, ${ }^{138}$ ruling that federal laws cannot "commandeer" state

Fox Co., 220 N.W. 697 (Mich. 1928); People v. Love, 391 N.W.2d 738 (Mich. 1986)).

131. See William Hubbs Rehnquist (1924-2005): Biographical Data, CoRnell Legal Info. INST., http://www.law.cornell.edu/supct/justices/rehnquist.bio.html (last visited Mar. 1, 2012).

132. Id.

133. Id.

134. See William H. Rehnquist, Oyez Project at IIT Chicago-Kent College of LaW, http://www.oyez.org/justices/william_h_rehnquist (last visited Mar. 1, 2012).

135. Id.

136. Erwin Chemerinsky, Keynote Address at the Willamette Law Review Symposium (Mar. 11, 2005), in 41 WILLAMETTE L. REV. 827, 834-35 (2005).

137. Id. at 828.

138. Nat'l League of Cities v. Usery, 426 U.S. 833, 851-52 (1976), overruled by Garcia v. San Antonio Metro. Transit Auth., 469 U.S. 528 (1985). 
governments to implement their policies, ${ }^{139}$ and holding for the first time that the federal commerce power has limits that Congress may not exceed. ${ }^{140}$ By the time of his death of 2005, Rehnquist's conservative imprint on the Court was clearly secure, and it may well prove to be his most enduring legacy.

\section{A Conservative Judicial Philosophy}

It is of course difficult to fully describe the nuances of a conservative judicial philosophy in a few short pages. The views of Bickel, Scalia, and Rehnquist, however, do help identify a few particularly important principles that will suffice to assess whether the Court's arbitration jurisprudence during the ascension of its conservatism was consistent with that conservatism. The first principle, from Bickel, is that of restraint-courts should rule narrowly and avoid deciding issues of policy that are properly in the province of the other political branches. ${ }^{141}$ The second principle, from Justice Scalia, extends the first to the construction of statutes by urging that the words of the statute themselves be the primary unit of interpretation without regard to amorphous terms like "intent," "purpose," and "history" that can be easily manipulated by preference. $^{142}$ Finally, from Chief Justice Rehnquist, we get an appreciation of the broad sphere of states' rights and the narrow reach of federal power, as well as a scent of the Republican political agenda. ${ }^{143}$ While not the totality of the conservative judicial philosophy, these principles are sufficiently important to provide reasonable modes of analysis of the bellwether cases I have identified.

\section{REVISITING THE BELLWETHER FAA CASES THROUGH A CONSERVATIVE LENS}

Having identified the Court's bellwether FAA cases in Part II and at

139. New York v. United States, 505 U.S. 144, 161 (1992).

140. See United States v. Lopez, 514 U.S. 549, 551 (1995) (holding that the Gun-Free School Zones Act of 1990 exceeds Congress' power to regulate commerce), superseded by statute, 18 U.S.C. § 922(q) (2006); United States v. Morrison, 529 U.S. 598, 627 (2000) (determining that the Violence Against Women Act exceeds Congress’ power under the Commerce Clause).

141. See supra Part III.A.

142. See supra Part III.B.

143. See supra Part III.C. I do not mean to suggest that the Chief Justice operated with a partisan bias favoring the Republican Party. Rather, I am simply reiterating the conventional wisdom that Justices tend to reflect the ideology of their appointing president. 
the least the basics of a conservative judicial philosophy in Part III, I now 
come to the crux of this Article-applying the conservative criteria to the cases.

\section{A. Prima Paint and Separability}

In Prima Paint, the Supreme Court dramatically expanded the scope of arbitral power by allowing arbitrators to decide the validity of the document giving rise to the arbitrator's jurisdiction if the arbitration provision was included in a larger contract. ${ }^{144}$ In the view of the Prima Paint Court, the arbitration clause was a "separate" contract from the larger contract, and if the arbitration provision broadly included all disputes arising under the agreement, then a dispute over the validity of the larger contract would simply be one such dispute. ${ }^{145}$ For this reason, the rule of Prima Paint has come to be known as the "separability" doctrine. ${ }^{146}$

I have criticized this decision at length elsewhere, ${ }^{147}$ but here I look at it from the perspective of consistency with conservative judicial principles and contend that a court applying conservative principles would not have reached the result that the Court did in Prima Paint. While issues of federalism do not significantly present themselves in this case, issues of role and statutory interpretation certainly do.

The Bickelian perspective respects institutional competence, and indeed, one of the central reasons why Bickel argued in favor of the passive virtues was because of courts' limited institutional capacity to decide questions of policy. ${ }^{148}$ The separability doctrine directly contradicts principles of institutional competence because it puts arbitrators, rather than courts, in the position of deciding questions of law-to wit, the legal validity of the contract containing an arbitration provision. As Justice Black famously exclaimed in dissent in Prima Paint:

The Court holds, what is to me fantastic, that the legal issue of a contract's voidness because of fraud is to be decided by persons designated to arbitrate factual controversies arising out of a valid contract between the parties. And the arbitrators who the Court holds

\footnotetext{
144. See Prima Paint Corp. v. Flood \& Conklin Mfg. Co., 388 U.S. 395, 402 (1967); see also supra Part II.B.1.

145. See Reuben, supra note 41 , at 838-40.

146. See supra note 41 and accompanying text.

147. See Reuben, supra note 41, at 841-48 (criticizing Prima Paint's holding on separability).

148. See supra Part III.A.
} 
are to adjudicate the legal validity of the contract need not even be lawyers, and in all probability will be nonlawyers, wholly unqualified to decide legal issues, and even if qualified to apply the law, not bound to do so.... I am fully satisfied that a reasonable and fair reading of [the FAA's] language and history shows that both Congress and the framers of the Act were at great pains to emphasize that nonlawyers designated to adjust and arbitrate factual controversies arising out of valid contracts would not trespass upon the courts' prerogative to decide the legal question of whether any legal contract exists upon which to base an arbitration. ${ }^{149}$

The opinion fares no better under principles of Scalian conservative textualism. The central FAA provision in play was section 4, which provides a remedy for a party seeking to enforce an arbitration agreement by permitting the enforcing party to go to a federal district court to compel the resisting party into arbitration. ${ }^{150}$ The statute assigns the court the duty of determining whether there is a valid agreement to arbitrate, and if the court determines after a hearing that there is, then the statute says that the court shall issue an order compelling the parties to proceed to arbitration according to the terms of the agreement; otherwise, the parties proceed directly to trial. ${ }^{151}$ The statute, thus, contemplates the judiciary as the gatekeeper for agreements to arbitrate. When there is a dispute about its validity, and a court determines the clause is valid, the agreement is enforced. ${ }^{152}$

The difficult interpretive question, of course, is the meaning of the language "and upon being satisfied that the making of the agreement for arbitration or the failure to comply therewith is not in issue." ${ }^{\text {„53 }}$ The Court's construction of it applying only to the arbitration clause, rather than the contract as a whole, is certainly plausible, but it is quite a reach given the overall structure of the FAA and the central role it posits for courts as gatekeepers for the arbitration system-a context that

149. Prima Paint, 388 U.S. at 407-08 (Black, J., dissenting).

150. 9 U.S.C. $\S 4$ (2006). The key language states in relevant part:

The court shall hear the parties, and upon being satisfied that the making of the agreement for arbitration or the failure to comply therewith is not in issue, the court shall make an order directing the parties to proceed to arbitration in accordance with the terms of the agreement. ... If the making of the arbitration agreement or the failure, neglect, or refusal to perform the same be in issue, the court shall proceed summarily to the trial thereof.

Id.

151. Id.

152. Id.

153. Id. 
traditionally informs textual analysis. ${ }^{154}$ But the Court eschews such analysis in favor of a more creative interpretation that treats arbitration clauses as separate contracts from the larger substantive contract in which they are embedded, making arbitration clauses unique from all other contract clauses in the law as far as I know. This interpretation further frustrates another foundational principle or maxim of statutory interpretation - that statutes should be interpreted to avoid absurd results, such as a non-lawyer arbitrator deciding questions of law (to wit, the validity of the document giving rise to their jurisdiction). ${ }^{155}$

In my view, a more restrained, conservative reading of this language would consider this statutory clause in light of the overall structure of the FAA and compel a conclusion that the court, not the arbitrator, would need to decide the question of the larger container contract. If the container contract is void, then all of the terms of the contract are void as well, including the arbitration clause.

\section{B. Southland and Preemption}

In Southland, the Supreme Court held that the FAA preempts contrary state laws - in this case, a California Franchise Investment Law provision barring the arbitration of claims brought under it. ${ }^{156}$ This obviously implicates the federalism principle of judicial conservatism, but it also raises issues of restraint and textualism. For the sake of analytical clarity, however, I begin by exploring the federalism issue.

Preemption is strong medicine for judicial conservatives like Rehnquist because it effectively displaces important state policies with a

154. The Court in United Savings Ass'n of Texas v. Timbers of Inwood Forrest Associates, Inc. discussed textual analysis, stating:

Statutory construction ... is a holistic endeavor. A provision that may seem ambiguous in isolation is often clarified by the remainder of the statutory scheme-because the same terminology is used elsewhere in a context that makes its meaning clear, or because only one of the permissible meanings produces a substantive effect that is compatible with the rest of the law.

484 U.S. 365, 371 (1988) (citations omitted). For a general discussion of the textualist approach, see Frank B. Cross, Essay, The Significance of Statutory Interpretive Methodologies, 82 NOTRE DAME L. REV. 1971, 1972-74 (2007).

155. The classic case on the absurdity doctrine is Holy Trinity Church v. United States. 143 U.S. 457, 459-61 (1892). For a concise discussion of the absurdity doctrine, see Andrew S. Gold, Absurd Results, Scrivener's Errors, and Statutory Interpretation, 75 U. CIN. L. REV. 25, 53-56 (2006). For a more comprehensive treatment, and a call to curtail the doctrine, see John F. Manning, The Absurdity Doctrine, 116 HARV. L. REV. 2387 (2003).

156. 465 U.S. 1,16 (1984). 
federal rule, and as such, the Court has only recognized preemption as appropriate in three circumstances. The first is direct or express preemption, where Congress has explicitly stated its intent to preempt contrary state laws. ${ }^{157}$ The second is implied or field preemption, where "Congress [has] left no room for the States to supplement [the federal statute]." 158 Finally, there is conflict preemption, where it would be simply impossible for the state and federal law to coexist as a practical matter. ${ }^{159}$

The FAA is silent on the preemption issue of preemption, ${ }^{160}$ meaning that if preemption is to be justified in a principled way, it must be either field or conflict preemption. Of the two, conflict preemption seems most implausible in that the FAA and contrary state laws could plainly exist side by side as different regimes covering different types of claims in different jurisdictions. Indeed, this is precisely what Congress intended, wrote Justice O’Connor in her Southland dissent. “One rarely finds a legislative history as unambiguous as the FAA's. That history establishes conclusively that the 1925 Congress viewed the FAA as a procedural statute, applicable only in federal courts, derived, Congress believed, largely from the federal power to control the jurisdiction of the federal courts."161 As conceived by the Act's drafters, she argued, those seeking to enforce arbitration agreements relating to federal claims in federal courts would rely on the FAA, while those pursuing arbitrations at the state level would use the similar state laws that all states have adopted. ${ }^{162}$ Even if one disagrees with Justice O’Connor's view of the clarity of the legislative history, to the extent that conflict preemption is predicated on necessity because the federal and state regimes simply will not work together, the FAA in no way meets that standard.

That leaves the possibility of field preemption, where Congress's regulation of the field is so pervasive that it leaves little room for the states to act, thus evidencing an intent to occupy the field. ${ }^{163}$ As noted above, however, the FAA hardly embodies a comprehensive regulatory

\footnotetext{
157. Gade v. Nat'l Solid Wastes Mgmt. Ass'n, 505 U.S. 88, 98 (1992).

158. Id. (quoting Rice v. Santa Fe Elevator Corp., 331 U.S. 218, 230 (1947)) (internal quotation marks omitted).

159. Id.

160. See 9 U.S.C. §§ 1-16 (2006).

161. Southland, 465 U.S at 25 (O’Connor, J., dissenting).

162. Id. at 31-33; see also Richard C. Reuben, Personal Autonomy and Vacatur After Hall Street, 113 PENN ST. L. REV. 1103, 1152 (2009) (noting that all states have passed either the Uniform Arbitration Act or its successor, the Revised Uniform Arbitration Act).

163. See supra note 158 and accompanying text.
} 
regime. ${ }^{164}$ To the contrary, it simply establishes a rule that permits the enforcement of agreements to arbitrate, sets rudimentary default rules for the operation of arbitration proceedings, and provides for the enforceability of arbitral awards and the conditions under which such awards may be set aside or modified. ${ }^{165}$ Many other issues remain open for state regulation, such as the availability of punitive damages, rules of discovery, and the confidentiality of arbitration proceedings. It is no small irony that the Revised Uniform Arbitration Act and its predecessor, the Uniform Arbitration Act, deal precisely with these issues. ${ }^{166}$ Because we know there is room for states to act because they have, in fact, acted, field theory is also not a compelling justification for preemption.

As we can thus see, no theory of preemption justifies the holding in Southland. Therefore, it is not surprising that Chief Justice Burger's opinion avoided the topic entirely and instead made the argument that preemption was necessary because of Congress' reliance on the Commerce Power in adopting the FAA. ${ }^{167}$ This is, however, a factual question that Justice O'Connor sharply disputed, as she claimed that the constitutional authority for the FAA was not the Commerce Clause but rather the constitutional power of Congress to control the jurisdiction of the federal courts. ${ }^{168}$ Reasonable minds can, and do, disagree on this issue. $^{169}$ But in making a Commerce Clause claim for preemption instead of adopting a more traditional preemption analysis, we can at least conclude that Chief Justice Burger was reaching for a rationale, if not a result.

This is precisely what Bickel would have counseled the Chief Justice against. Bickel called for restraint and urged courts to use such technicalities as standing, ripeness, and other procedural barriers to access to avoid judicial decision-making unless it was necessary for the court to decide the dispute. ${ }^{170}$ Thus, his notion of restraint went further

164. See supra Part II.A.

165. See supra Part II.A.

166. See Timothy J. Heinsz, The 2000 Revision to the Uniform Arbitration Act: A Harbinger?, 3 PEPP. DisP. RESOL. L.J. 435, 435-41 (2003) (providing a summary of the Revised Uniform Arbitration Act by its reporter).

167. Southland, 465 U.S. at 11-13.

168. Id. at 28 (O’Connor, J., dissenting).

169. See Christopher R. Drahozal, In Defense of Southland: Reexamining the Legislative History of the Federal Arbitration Act, 78 NOTRE DAME L. REV. 101 (2002) (providing an excellent account of the scholarly and judicial criticism of Southland and an attempt to demonstrate that the holding was at least plausible, if not compellingly reasoned).

170. See supra notes 100-03 and accompanying text. 
than merely avoiding decisions on social policy best left to the political branches, but instead called upon courts not to act at all unless they really have to. Put another way, the less the courts rule on substantive issues, the less likely they will be to inadvertently decide questions of policy, and the more authority and capital they will have when they do speak. Such a restrained view would surely expect a congressional intent to preempt to be quite explicit rather than judicially imposed and would at least stay within the boundaries of traditional preemption analysis.

Finally, while the federalism arguments are compelling in and of themselves, they are also well supported by Scalian textualism. The FAA is replete with references to the federal courts and federal law and virtually devoid of any references to state courts and state law. Section 3's stay provision, for example, opens by providing "[i]f any suit or proceeding be brought in any of the courts of the United States."171 Section 4's provisions for compelling arbitration similarly empower "[a] party aggrieved by the alleged failure, neglect, or refusal of another to arbitrate under a written agreement for arbitration [to] petition any United States district court which ... would have jurisdiction under Title 28." 172 The section also makes references to the Federal Rules of Civil Procedure. ${ }^{173}$ Finally, section 10's vacatur provisions authorize "the United States court in and for the district wherein the award was made [to] make an order vacating the award" under specified circumstances, but they provide no such authorization for vacatur by state courts. ${ }^{174}$

Thus, applying the Whole Act Rule of statutory interpretation-a statutory maxim well within the boundaries of textualist analysis-one could only conclude that the FAA was intended to apply in federal courts, not in state courts. Again, my point is not to provide yet another argument as to why Southland was wrongly decided. Rather, it is to suggest simply that Southland would have gone the other way if it had been decided under the conservative juridical principles of restraint, fidelity to text, and states' rights.

171. 9 U.S.C. $\S 3$ (2006).

172. Id. § 4 .

173. Id.

174. Id. § 10 . 


\section{Gilmer and the Mandatory Arbitration of Statutory Claims}

In Gilmer, the Supreme Court effectively upheld the validity of mandatory arbitration clauses in standard form contracts. ${ }^{175}$ It was the coda on a remarkable about-face by the Court on the issue of whether arbitration could be used to deny parties access to the public courts for statutory claims.

This was the question presented in the first significant case decided under the FAA, Wilko v. Swan. ${ }^{176}$ In Wilko, the Court found that mandatory arbitration clauses in securities brokerage agreements were not enforceable under the FAA because "the right to select the judicial forum is the kind of 'provision' that cannot be waived" under the Securities Act of 1934. ${ }^{177}$ The Wilko doctrine thus assured that, at least as to statutory claims, arbitration did not bar access to the courts.

The shift began just seven years later with the Steelworkers Trilogy of 1960, as the Court articulated its policy preference for arbitration as the primary method of dispute resolution in labor relations and called for any doubts as to arbitrability to be decided in favor of arbitrability. ${ }^{178}$ The Court took care to steer its holdings away from the commercial context and keep them focused on the collective bargaining context, where arbitration effectively substitutes for worker strikes. ${ }^{179}$ A quarter of a century later, however, the Court obliterated that distinction in Moses H. Cone Memorial Hospital v. Mercury Construction Corp., holding that the purpose of the FAA was to create a body of federal substantive law that governs in either state or federal courts and introducing language into arbitration jurisprudence that provided a cornerstone for much of the Court's later work:

Section 2 is a congressional declaration of a liberal federal policy favoring arbitration agreements, notwithstanding any state substantive or procedural policies to the contrary.... [Q]uestions of arbitrability must be addressed with a healthy regard for the federal policy favoring arbitration.... The Arbitration Act establishes that, as a matter of

175. 500 U.S. 20, 30-33 (1991).

176. 346 U.S. 427, 430 (1953), overruled by Rodriguez de Quijas v. Shearson/Am. Express, Inc., 490 U.S. 477 (1989).

177. Id. at 434-35.

178. United Steelworkers v. Am. Mfg., 363 U.S. 564, 569 (1960); United Steelworkers v. Warrior \& Gulf Navigation Co., 363 U.S. 574, 585 (1960); United Steelworkers v. Enter. Wheel \& Car Corp., 363 U.S. 593, 599 (1960).

179. Am. Mfg., 363 U.S. at 567; Warrior \& Gulf, 363 U.S. at 578; Enter. Wheel, 363 U.S. at 598-99. 
federal law, any doubts concerning the scope of arbitrable issues should be resolved in favor of arbitration....

Two years later, in 1985, the Court affirmed the arbitrability of statutory claims in Mitsubishi Motors Corp. v. Soler Chrysler-Plymouth Inc., finding that without "compelling considerations, the Act itself provides no basis for disfavoring agreements to arbitrate statutory claims by skewing the otherwise hospitable inquiry into arbitrability."181 By the late 1980s, there was little for the Court to do but formally reverse the ouster doctrine, which it did in 1989 in Rodriguez de Quijas v. Shearson/American Express, Inc. ${ }^{182}$

Gilmer extended these cases and opened the door to the use of arbitration agreements for the wide variety of consumer and employment disputes that we see today. It has also been widely criticized, but the question for purposes of this Article is simply whether the result would have been different if it had been decided by a truly conservative Court. Our inquiry is initially complicated by two issues, ignored by the Gilmer Court, that were vital to the Court's decision and to Gilmer's enduring legacy of controversy-consent and standard form contracts. ${ }^{183}$

Consent is an issue because the decision to arbitrate under the FAA is a volitional and consensual act, as the Court has long recognized. ${ }^{184}$ Standard form contracts are an issue because the law generally assumes that parties have consented to all terms, even though most people do not. ${ }^{185}$ The actual consent to arbitrate assumed by the FAA and the presumed intent imputed by the law of standard form contracts do not easily square with one another. This was the heart of the subtextual fight in Gilmer. ${ }^{186}$ Assuming the validity of standard form contracts (as the Gilmer Court did), is it appropriate for a standardized contract to include a provision that waives the rights of employees to have courts decide whether rights granted to them legislatively have been violated, given that the FAA appears to call for actual consent?

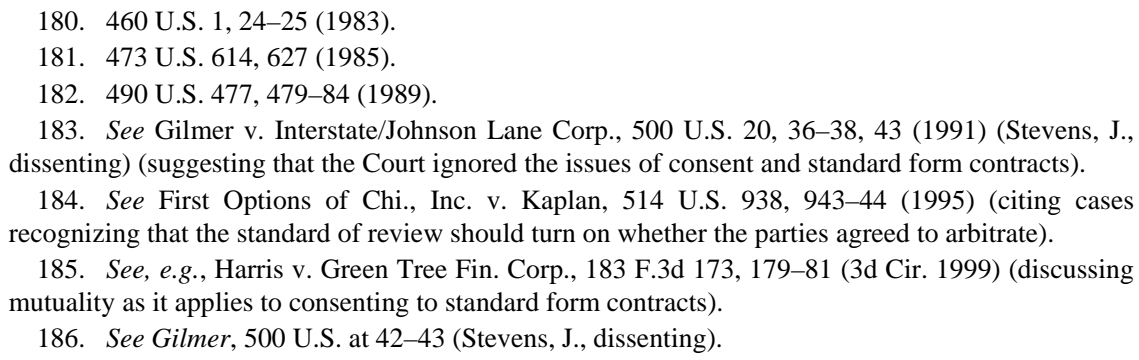


As previously discussed, a generation before, the Wilko Court had decided that the answer to this question was "no" and that the right to take a statutory claim was not the "kind of right" that could be waived through an arbitration clause. ${ }^{187}$ But as was also discussed, the Court formally repudiated that rule in the Shearson cases, holding that consumer claims under federal securities laws may be subject to arbitration. ${ }^{188}$ One way to look at Gilmer, then, is as a mere extension to the employment context of the Shearson rule that consumer statutory claims could be subject to arbitration. Such an interpretation does little to offend the principles of conservative jurisprudence.

Gilmer went much farther, however, because it reversed the presumption, previously unquestioned, that Congress intended for statutory claims to be brought in courts of law. ${ }^{189}$ Rather than beginning with public trial as the default for statutory enforcement, the Gilmer Court placed the burden on the plaintiff "to show that Congress intended to preclude a waiver of a judicial forum for [statutory] claims.” ${ }^{\text {190 }}$ As Justice White further wrote for the Court:

If such an intention exists, it will be discoverable in the text of the [statute], its legislative history, or an "inherent conflict" between arbitration and the [statute's] underlying purposes. Throughout such an inquiry it should be kept in mind that "questions of arbitrability must be addressed with a healthy regard for the federal policy favoring arbitration."191

Justice White did not stop there. He set a nearly insurmountable bar for what constitutes an inherent conflict between the private arbitral forum and the vindication of the statute's intent by making clear the Court's view that the change in decisional forum from public courts to arbitration is just a change of forum that does not affect substantive rights. ${ }^{192}$ He rejected the argument that the remedial function of public adjudication of statutory claims can be lost in arbitration, ${ }^{193}$ and he

188. Rodriguez de Quijas, 490 U.S. at 479-84; Shearson/Am. Express, Inc. v. McMahon, 482 U.S. 220, 238 (1987).

189. Gilmer, 500 U.S. at 26.

190. Id.

191. Id. (citation omitted) (quoting Moses H. Cone Mem’l Hosp. v. Mercury Constr. Corp., 460 U.S. 1, 24 (1983)).

192. Id.

193. Id. at $27-28$. 
summarily dismissed generalized concerns, such as arbitral bias and the accurate application of the law, as old hostility to arbitration. ${ }^{194}$ Such claims may be established in particular cases, Justice White noted, but provide no basis for a general challenge to arbitration today. ${ }^{195}$

So it is against this necessary background that we can finally turn to the question of Gilmer's fidelity to conservative judicial principles. From a Bickelian perspective of restraint, the Court clearly overstepped its bounds in two ways. First, it did far more than simply decide the question before it, which was the arbitrability of ADEA claims. ${ }^{196}$ Rather, casting restraint aside, it reached out and reversed the normal presumption that Congress intended statutory claims to be brought in court and instead required plaintiffs to show that Congress intended to preclude the arbitration of claims and, further yet, set an extraordinarily high bar for making such claims. ${ }^{197}$ Second, and perhaps more troubling for a Bickelian conservative, the Court decided an important question of policy that should have been left to the political branches: the legitimacy of mandatory arbitration. ${ }^{198}$ This is clearly a question of policy upon which reasonable people can and do very deeply disagree, and by that standard alone, it is one that should be decided by the legislature rather than the courts. ${ }^{199}$ The Court has no competence to bring to the question of mandatory arbitration, only preference, and the legitimacy of any decision on that issue would only benefit from its vetting through the many voices and stages of the legislative process. By deciding this policy question itself rather than deferring it to the political branches, the Court crossed the line that separates mere conservatism from conservative activism. ${ }^{200}$

From a textualist perspective, Gilmer is less problematic. Looking first at the FAA, the Court's decision is justified in that section 2's savings clause only calls for the repudiation of an agreement to arbitrate "upon such grounds as exist at law or in equity for the revocation of any contract." 201 As noted above, the complicating factor here is that the

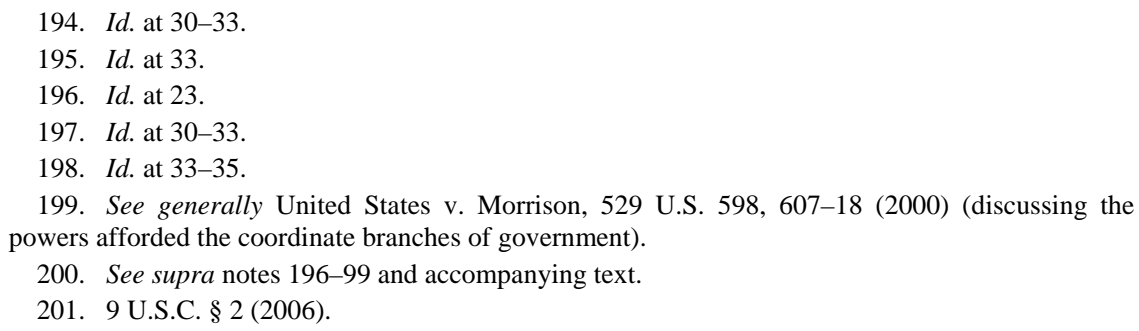


agreement to arbitrate is presumed because the clause appears in a standard form contract. ${ }^{202}$ While controversial during their earlier years, standard form contracts today have become commonplace. Standard form contracts are generally valid today if they are conscionable, and if we set aside as otherwise resolved the Wilko question of whether a party may properly waive court access rights in a standard form contract, then the Gilmer holding does not offend principles of textualism. The FAA does not specifically, or by its terms impliedly, preclude the inclusion of arbitration provisions in standard form contracts for employment. ${ }^{203}$ The ADEA does not expressly preclude the arbitration of age discrimination claims, and so a ruling that Gilmer's ADEA claim can be compelled into arbitration surely would not offend textualist principles.

From a federalism perspective, however, Gilmer is far more troubling, especially when considered in concert with Southland's rule of preemption. Read together, they essentially mean that states can do little to protect their citizens when franchisors, service providers, employers, and other institutional players choose to put arbitration provisions in their standard form contracts. This is not mere conjecture. After Gilmer, Montana, for example, passed a law requiring consumer, employer, and other standard form contracts with arbitration provisions to simply put those provisions in underlined capital letters on the first page of the contract. $^{204}$ The Supreme Court, in Doctor's Associates, Inc. $v$. Casarotto, held that the FAA preempted this statute because it was hostile to arbitration in that it invalidated the arbitration provisions of non-complying contracts. ${ }^{205}$ From a federalism perspective, it is telling that two justices of the Montana Supreme Court refused to sign the remand order returning the case from the U.S. Supreme Court to the lower Montana courts, calling the Supreme Court's decision "philosophically misguided" in their symbolic protest of federal intrusion into states' rights. ${ }^{206}$

\footnotetext{
202. See supra note 185 and accompanying text.

203. See supra notes 176-82, 188-98 and accompanying text.

204. MonT. Code ANN. § 27-5-114(4) (1989), preempted by 9 U.S.C. § 2, as recognized in Doctor's Assocs., Inc. v. Casarotto, 517 U.S. 681, 688 (1996).

205. 517 U.S. at $687-88$.

206. Richard C. Reuben, Western Showdown: Two Montana Judges Buck the U.S. Supreme Court, A.B.A. J., Oct. 1996, at 16 (internal quotation marks omitted).
} 


\section{Circuit City and the Employee Exemption}

In Circuit City, a sharply divided Court held that the employee exemption in section 1 was limited to employees in the transportation industry. ${ }^{207}$ Federalism and restraint have less bearing on the analysis than textualism, so it is there that I will focus my discussion.

Despite its logical appeal, textualism has been criticized for its rigid formalism and impracticability given the variety of meanings that can be attached to words, as well as the natural instinct to interpret words in the larger written and environmental contexts in which they are expressed. ${ }^{208}$ Indeed, this criticism suggests that textualism provides no greater protection against the imposition of the personal policy preferences of the decision maker than traditional statutory analysis, which looks first to the text and then to the intent, purpose, and history of the statute to derive proper statutory interpretation. ${ }^{209}$ In this regard, Circuit City provides a good example of problems with strong textualism.

Again, section 1 of the FAA provides the critical language, exempting from coverage of the Act "contracts of employment of seamen, railroad employees, or any other class of workers engaged in foreign or interstate commerce." 210 So, on the face of the statute, the language "any other class of workers engaged in foreign or interstate commerce" ${ }^{211}$ would appear to unambiguously exclude workers from the reach of the statute. This was the point of the Circuit City dissenters, who accused the majority of "playing ostrich" by refusing to consider the legislative history of the exemption. ${ }^{212}$ "History amply supports the proposition that it was an uncontroversial provision that merely confirmed the fact that no one interested in the enactment of the FAA ever intended or expected that $\S 2$ would apply to employment contracts." 213

But in his majority opinion, Justice Kennedy extended his textual analysis beyond the language of the statute to draw upon a judicial

207. 532 U.S. 105, 109 (2001).

208. See, e.g., William N. Eskridge, Jr. \& Philip P. Frickey, Statutory Interpretation as Practical Reasoning, 42 STAN. L. REV. 321, 340-45 (1990) (criticizing textualism as a foundational approach to statutory interpretation).

209. See Eskridge, supra note 123, at 626-40 (discussing traditional considerations in statutory interpretation).

210. 9 U.S.C. $\S 1$ (2006).

211. Id.

212. 532 U.S. at 128 (Stevens, J., dissenting).

213. Id. 
maxim of statutory interpretation, ejusdem generis, under which a general, residual clause-here the workers exemption-should be controlled by the preceding terms. ${ }^{214}$ That had a narrowing effect here, Kennedy observed, because it compelled the Court to read the "any class of workers" residual clause as being limited to the kinds of workers identified in the preceding terms, "seamen" and "railroad employees."215 As a result, otherwise qualifying disputes involving all other nontransportation workers would still fall within the FAA.

But if "new textualism" "16 is to be taken seriously, there was no need to resort to canons of interpretation because the text was unambiguous as previously described. Moreover, while canons of statutory interpretation seem to carry unusual gravitas by their test of time, they are hardly consistent and easily manipulable. ${ }^{217}$ As Professor Llewellyn pointed out more than a half century ago, for any canon of statutory interpretation, one can find another canon that compels a court to reach the opposite conclusion. $^{218}$ In the case of the ejusdem generis canon, for example, one could just as easily have reached the opposite result using the judicial maxim holding "ejusdem generis is only an aid in getting the meaning and does not warrant confining the operations of a statute within narrower limits than were intended," ${ }^{, 19}$ or even more pointedly, "[i]f language is plain and unambiguous it must be given effect.",220

Though perhaps compelled by preference to outcome, ${ }^{221}$ the Court clearly was not required to resort to the ejusdem generis maxim in the interpretation of this statutory language-although the outcome might have been different if the Court had merely adhered to the unambiguous language of the statute. The majority made a choice, and that choice represented the personal preferences of the five "conservative"

214. Id. at $114-15$ (majority opinion).

215. Id. at 118-19.

216. See Eskridge, supra note 123, at 623-24 (briefly describing the new textualism approach to statutory interpretation).

217. See id. at 675 (noting canons are "notoriously numerous and manipulable").

218. See Karl N. Llewellyn, Remarks on the Theory of Appellate Decision and the Rules or Canons About How Statutes Are to Be Construed, 3 VAND. L. REV. 395, 401-06 (1950) (listing contradictory canons of statutory interpretation).

219. Id. at 405 .

220. Id. at 403.

221. Circuit City Stores, Inc. v. Adams, 532 U.S. 105, 118 (2001) (noting that the FAA's statutory context and purpose compelled the Court to construe section 1 narrowly). 
Justices-Kennedy (its author), Rehnquist, O’Connor, Scalia, and Thomas. ${ }^{222}$

\section{E. Concepcion and Class Arbitration}

As a formal matter, the most recent of the bellwether cases, Concepcion, simply held that state rules regarding the unconscionability of class action waivers are preempted by the FAA. ${ }^{223}$ Two aspects of the case, however, are salient for our purposes-the Court's discussion of class actions and its holding on section 2's savings clause.

On the class action side, Concepcion is the latest in a line of decisions that almost surely will come to hold that class actions generally may not be brought in arbitration under the FAA. "Arbitration is poorly suited to the higher stakes of class litigation," Justice Scalia wrote for the 5-4 majority, noting the lack of substantive review of arbitration awards. ${ }^{224}$ Justice Scalia also noted that " $[\mathrm{w}] \mathrm{e}$ find it hard to believe that defendants would bet the company with no effective means of review, and even harder to believe that Congress would have intended to allow state courts to force such a decision.”225 This language echoes passages in Justice Alito's 2011 opinion in Stolt-Neilsen S.A. v. AnimalFeeds International Corp., in which Justice Alito wrote that "[w]e think that the differences between bilateral and class-action arbitration are too great for arbitrators to presume, consistent with their limited powers under the FAA, that the parties' mere silence on the issue of class-action arbitration constitutes consent to resolve their disputes in class proceedings."226

Such language in the Court's two most recent arbitration opinions appears to spell doom for the future availability of class procedures in arbitration under the FAA. To be sure, carving out class actions may or may not be a good idea for the reasons that the Court describes. ${ }^{227}$ But from a Bickelian perspective, this is not the Court's decision to make. Indeed, even if viewed from the contract-based perspective that has characterized much of the Court's arbitration jurisprudence, ${ }^{228}$ the

\footnotetext{
222. Id. at 107.

223. 131 S. Ct. 1740,1753 (2011).

224. Id. at 1752.

225. Id.

226. 130 S. Ct. 1758,1776 (2010).

227. See supra notes $225-26$ and accompanying text.

228. See generally Ware, supra note 59 (discussing the contract-based perspective of arbitration jurisprudence).
} 
decision of whether to use class actions in arbitration is a strategic choice of the parties in the first instance. If they want to have an arbitrator decide a class action, who is the Court to say they cannot? The FAA clearly does not preclude the use of class procedures, and in fact, one of the nation's leading providers of arbitration services, the American Arbitration Association, has long had specific procedures for class arbitrations. ${ }^{229}$ If we are to preclude the possibility of party choice of class arbitration, then that decision should come from the parties or elected legislature, not from the appointed courts.

Moreover, if that choice is to be subject to regulation, then principles of institutional competence compel that decision to be made by the political branches, not appointed courts. This question is a value-laden one of policy that should be decided on the basis of debate within the political sphere, where affected constituents can work to educate legislators and the public, and marshal their resources to achieve their preferred legislative outcome. Judges trained to apply rules have no competence with which to make this policy choice other than personal or institutional preference-bases that a true conservative judicial philosophy abhors.

As troubling as this aspect of the opinion is from the perspective of true judicial conservatism, more troubling is the majority's ruling on the savings clause issue. As discussed above, section 2 permits the enforcement of agreements to arbitrate unless the agreement may be voided "upon such grounds as exist at law or in equity for the revocation of any contract." 230 Since contract law is primarily a creature of state law, this language has preserved an important role for the states, including the state courts, in assuring that parties compelled into arbitration actually agreed to do so in the first place. In this era of standardized form arbitration agreements, it has provided a means of policing adhesive arbitration provisions, primarily through the application of state unconscionability doctrines. ${ }^{231}$

That is precisely what happened in Concepcion. The California Supreme Court, interpreting its state's general law of unconscionability in Discover Bank, identified certain conditions under which class action

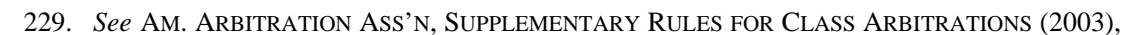
available at http://www.adr.org (follow "Search Rules” hyperlink; then search "Class Arbitration”; then follow "Supplementary Rules for Class Arbitration" hyperlink).

230. 9 U.S.C. $\S 2$ (2006).

231. See Concepcion, 131 S. Ct. at 1746-48 (discussing the application of California's unconscionability doctrine). 
waivers will render an arbitration clause unconscionable-when the damages are small and the party with superior bargaining power has engaged in a deliberate scheme of stealing small sums of money from large numbers of people. ${ }^{232}$

The Discover Bank rule was simply the application of a general rule of state contract law to the specific context of arbitration. Ordinarily, a state supreme court's interpretation of its own state statutes is entitled to enormous deference by the Court. ${ }^{233}$ The Scalia majority, however-in the Court's first construction of the savings clause-found that "nothing in [the clause] suggests an intent to preserve state-law rules that stand as an obstacle to the accomplishment of the FAA's objectives." ${ }^{\text {,234 }}$ Applying this principle to hold the California Supreme Court's Discover Bank rule preempted by the FAA demonstrates its remarkable encroachment on state contract police powers. Under Concepcion, a state supreme court's interpretation of a state contract law of general applicability will be preempted if it results in the invalidation of an arbitration clause. $^{235}$

The problem with this analysis, of course, is that the very purpose of the savings clause is to invalidate arbitration clauses when they are unenforceable as a matter of general state contract law. ${ }^{236}$ If taken seriously then, Concepcion renders the savings clause essentially meaningless, effectively ending state police authority over contracts with arbitration provisions. It is difficult to imagine an outcome more at odds with conservative notions of federalism. As Justice Breyer wrote in a dissent joined by Justices Ginsburg, Sotomayor, and Kagan:

"[B]ecause the States are independent sovereigns in our federal system, we have long presumed that Congress does not cavalierly pre-empt state-law causes of action.” But federalism is as much a question of deeds as words. It often takes the form of a concrete decision by this Court that respects the legitimacy of a State's action in an individual case. Here, recognition of that federalist ideal, embodied in specific

232. Id. at 1746 (citing Discover Bank v. Superior Court, 113 P.3d 1100, 1110 (Cal. 2005), abrogated by Concepcion, 131 S. Ct. 1740).

233. See Jason Mazzone, The Bill of Rights in the Early State Courts, 92 MinN. L. REv. 1, 56-58 (2007) (discussing deference to state court rulings on state law). The Court, however, has also been willing to ignore this rule when it wants. See, e.g., Bush v. Gore, 531 U.S. 98, 105-11 (2000) (per curiam) (refusing to defer to the Florida Supreme Court's interpretation of Florida election law).

234. Concepcion, $131 \mathrm{~S}$. Ct. at 1748. Given Justice Scalia's textualist aversion for legislative intent and legislative purpose, his choice of the word "objectives" is especially noteworthy.

235. Id.

236. See 9 U.S.C. § 2 (2006). 
language in this particular statute, should lead us to uphold California's law, not to strike it down. ${ }^{237}$

\section{CONCLUSION: FAA LAW WITHOUT THE ACTIVISM}

In an important article critical of the Court's ramp-up on mandatory arbitration, Professors Carrington and Haagen called the Court's arbitration jurisprudence a "shantytown" that puts the needy at the mercy of the most powerful in a second-class system of justice. ${ }^{238}$ As much as I agree with their sentiment, the image raised by the Court's work is very different for me.

As I look at the Court's arbitration jurisprudence, reflected in the five bellwether cases analyzed above, I am reminded not of ghettos and slums, but of opulence and arrogance at the wielding of raw, unchecked power. The image that comes to my mind is that of the legendary Orson Welles movie Citizen Kane, in which media magnate Charles Foster Kane built Xanadu, a colossal mansion made of the finest materials and decorated with art collected from around the world, which stood as a monument to Kane's wealth and power and to an inspiration for happiness that he could never find. ${ }^{239}$

Like Kane's Xanadu, the Court's arbitration jurisprudence is a monument to unchecked power as it has relentlessly pursued its own version of civil justice reform - a junior varsity private system of adjudication that allows powerful parties to use standard form contracts to strip unsuspecting consumers, employees, and others of their right to a day in court, or even application of the law. ${ }^{240}$ A system that assumes fairness of process but sets the highest of bars for complaints. ${ }^{241}$ And finally, a system that applies to all cases—state and federal, ${ }^{242}$ judicial

237. Concepcion, 131 S. Ct. at 1762 (Breyer, J., dissenting) (alteration in original) (quoting Medtronic, Inc. v. Lohr, 518 U.S. 470, 485 (1996)).

238. Carrington \& Haagen, supra note 25, at 401 (“As architecture, the arbitration law made by the Court is a shantytown. It fails to shelter those who most need shelter. And those it is intended to shelter are ill-housed. Under the law written by the Court, birds of prey will sup on workers, consumers, shippers, passengers, and franchisees; the protective police power of the federal government and especially of the state governments is weakened; and at least some and perhaps many commercial arbitrations will be made more costly while courts determine whether arbitrators have been faithful to certain federal laws.”).

239. CitizEn KANE (RKO Pictures 1941).

240. See supra Part IV.C.

241. See supra Part IV.C.

242. See supra Part IV.B. 
and administrative ${ }^{243}$ - except those, like class actions, that the Court, of its own accord, decides are inappropriate for arbitration. ${ }^{244}$ Like Kane, the Court has spared no expense and cut no corners in its construction, using its lavish "liberal federal policy favoring arbitration" 245 to give arbitrators the power to decide the most serious of legal issues even if they are not attorneys, ${ }^{246}$ to deny states the ability to pass laws in any way regulating arbitration agreements if that regulation would lead to the invalidation of an agreement to arbitrate, ${ }^{247}$ and now, most recently, to refuse to permit the application of even general contract law to an arbitration provision if it would interfere with the "purposes and objectives" of the FAA, however the Court chooses to define them. ${ }^{248}$

If judicial conservatism may be defined in terms of restraint and fidelity to text, and activism may be defined in terms of a court imposing its own agenda into the words of a rule, ${ }^{249}$ the forgoing analysis makes it difficult to escape the conclusion that the Court's arbitration jurisprudence has not fulfilled the promise of conservative presidents for a more conservative jurisprudence. To the contrary, it can only be characterized as results-oriented activism every bit as offensive to a principled jurisprudence as the excesses of the Warren Court a half century ago. ${ }^{250}$

Much of the Court's arbitration jurisprudence has been in the name of being pro-arbitration by supporting the theoretical agreement of the parties to arbitrate. Yet reasonable minds may disagree as to whether the

243. Preston v. Ferrer, 552 U.S. 346, 359 (2008) ("When parties agree to arbitrate all questions arising under a contract, the FAA supersedes state laws lodging primary jurisdiction in another forum, whether judicial or administrative.”).

244. See supra Part IV.E.

245. Moses H. Cone Mem'l Hosp. v. Mercury Constr. Corp., 460 U.S. 1, 24 (1983).

246. See supra Part IV.A.

247. See Doctor’s Assocs., Inc. v. Casarotto, 517 U.S. 681, 687-88 (1996).

248. See supra Part IV.E.

249. See Frank B. Cross \& Stefanie A. Lindquist, The Scientific Study of Judicial Activism, 91 MiNN. L. REV. 1752, 1754 (2007) (defining judicial activism as "actions that are more clearly grounded in a Justice's ideology than in legitimate legal sources"); see also id. at 1755-70 (providing a thorough discussion of some of the different understandings of "judicial activism").

250. As Justice O’Connor stated bluntly:

[O]ver the past decade, the Court has abandoned all pretense of ascertaining congressional intent with respect to the Federal Arbitration Act, building instead, case by case, an edifice of its own creation. I have no doubt that Congress could enact, in the first instance, a federal arbitration statute that displaces most state arbitration laws. But I also have no doubt that, in 1925, Congress enacted no such statute.

Allied-Bruce Terminix Cos. v. Dobson, 513 U.S. 265, 283 (1995) (O’Connor, J., concurring) (citation omitted). 
Court's arbitration jurisprudence is good for arbitration, and I for one am unconvinced, as legitimacy continues to elude arbitration just as happiness did Charles Foster Kane. Rare today is the popular article or news story extolling the virtues of arbitration. Far more common are stories about surprise and abuse in the arbitration process. ${ }^{251}$ Powerful and respected organizations, such as the Consumers Union, have taken positions against mandatory arbitration. ${ }^{252}$ While it is true that these are positions against mandatory arbitration and not all arbitration, the general public is not always so nuanced in its understanding.

As even the staunchest of arbitration advocates have recognized, arbitration as a dispute resolution process operates under a cloud that is by and large a product of the Court's activism. ${ }^{253}$ Like other institutions, dispute resolution processes depend heavily on public perceptions of their legitimacy. ${ }^{254}$ If the process is not perceived as legitimate, then parties will not use it-unless, as in the case of mandatory arbitration, they have no choice. Such compulsion exacts costs on the legitimacy of the larger rule of law system in which arbitration is embedded. ${ }^{255}$

So we end where we began, with the question of what arbitration would look like under the FAA without the activism and if the bellwether cases had been decided by a truly conservative Court. This is necessarily a speculative exercise, but here is my best guess.

For one, it would have a less prominent place in the universe of dispute resolution for a number of reasons. Most obviously, parties with superior bargaining power would not be able to impose it upon

251. See, e.g., Carrick Mollenkamp, Dionne Searcey, \& Nathan Koppel, Turmoil in Arbitration Empire Upends Credit-Card Disputes, WALL ST. J., Oct. 15, 2009, at A14; Bob Carlson, First Business, Now Health Care: Signing Away One's Right To Sue, MANAGEd CARE (June 2002), http://www.managedcaremag.com/archives/0206/0206.binding.html; All Things Considered: Rape Case Highlights Arbitration Debate (NPR radio broadcast June 9, 2009), available at http://www.npr.org/templates/story/story.php?storyId=105153315.

252. In 2005, the Consumers Union led more than two dozen consumer groups in urging the abolition of mandatory arbitration. Press Release, Consumers Union, Groups Launch Nationwide Effort to Stop Use of Binding Mandatory Arbitration Clauses (Feb. 24, 2005), available at http://www.consumersunion.org/pub/core_financial_services/002025.html.

253. Richard Chernick, Imposed-Arbitration Reforms Threaten to Stifle Strengths of Commercial Arbitration, DisP. RESOL. MAG., Fall 2002, at 16, 19.

254. The legitimacy of dispute resolution processes has been studied as a part of procedural justice. See Nancy A. Welsh, Making Deals in Court-Connected Mediation: What's Justice Got to Do with It?, 79 WASH. U. L.Q. 787, 817-58 (2001); see also Richard C. Reuben, Democracy and Dispute Resolution: The Problem of Arbitration, 67 LAW \& CONTEMP. PROBS. 279, 311-18 (2004) (discussing implications of legitimacy and compliance research on democracy and the rule of law).

255. See Reuben, supra note 254, at 309-18 (discussing the democratic consequences of mandatory arbitration). 
consumers, employees, franchisees, and other less powerful parties in standard form contracts of adhesion. Rather, the law would require an actual written agreement to arbitrate between the parties, ${ }^{256}$ which could certainly be pre-dispute as between parties of equal bargaining power.

FAA arbitration would also be less prominent because the FAA would only apply in federal courts, not state courts, and would not operate to preempt state laws that would invalidate agreements to arbitrate as unlawful contracts by reason of state policy. Rather than being overwhelmed by a distended federal policy favoring arbitration, state law applied by state court judges would be the primary determinant of the validity of an agreement to arbitrate, as with any other contractual term. ${ }^{257}$ Where general state contract law principles or specific rules of state public policy would invalidate the arbitration provision, it would simply be void. Crucially in this regard, the courts, not arbitrators, would play the crucial gatekeeping role of determining the validity of the arbitration agreement under applicable principles of state law. ${ }^{258}$

While arbitration might be a less visible feature of the dispute resolution landscape, it would, in my view, be a less controversial, more legitimate, and perhaps more popular instrument of dispute resolution than it is today. Because arbitration would be subject to the actual consent of the parties, actively policed by courts according to legal standards, and subject to other public policies, motions to compel arbitration would be relatively rare because the parties would actually want to be in arbitration. Put another way, parties would be in arbitration for the right reasons - that it makes the most sense in their opinion as a way to resolve a particular dispute-rather than being forced into arbitration against their will. There are many good reasons to choose arbitration-flexibility in decisional standards, speed, finality, and privacy to name just a few-and focusing clearly on these issues would underscore the practical utility of the process for those tasked with deciding upon a method of legal dispute resolution. ${ }^{259}$

Many of the most significant theoretical controversies in arbitration would also diminish. Mandatory arbitration would be off the table in favor of actual consent. The arbitrability of statutory claims would

\footnotetext{
256. See 9 U.S.C. § 2 (2006) (evidencing the “written provision” language).

257. See id.

258. See $\S 4$ (evidencing such a role for the courts).

259. See Richard C. Reuben, Process Purity and Innovation: A Response to Professors Stempel, Cole, and Drahozal, 8 NEv. L.J. 271, 278-84 (2007) (discussing the core process characteristics and values of commercial arbitration under the FAA).
} 
simply be a matter of consent, as would the availability of class actions in arbitration. The morass of manifest disregard would perhaps fade away because the distinction between public adjudication as a law-bound process and the arbitration process as a process not necessarily bound by law would be cleared rather than blurred. Creeping legalism and concerns about arbitration morphing into just another version of litigation ${ }^{260}$ would abate as willing parties would be better able to work with the arbitration process instead of against it. All of this would support the efficacy of arbitration as a viable and attractive dispute resolution option, and one far more legitimate than the bizarre and tilted world of FAA arbitration that the Court has molded through its creativity and activism. Arbitration would be, in other words, just as it should have been all along, and that would be good for arbitration.

260. See, e.g., Gerald F. Phillips, Is Creeping Legalism Infecting Arbitration?, DisP. REsOL. J., Feb.-Apr. 2003, at 37, 38 (noting that arbitration has become a legalistic method of adjudication); Perry A. Zirkel \& Andriy Krahmal, Creeping Legalism in Grievance Arbitration: Fact or Fiction?, 16 OHIO St. J. ON DisP. RESOL. 243, 258-59 (2 001) (same). 